\title{
Egészségfejlesztési irodák hálózata
}

\author{
Network of Health Promotion Offices
}

\author{
Szerző: $\quad$ Bezzegh Péter $\square$ \\ Nemzeti Egészségfejlesztési Intézet
}

Kulcsszavak: egészségfejlesztés; EFl; hálózatok; egészségfejlesztési iroda

Keywords: health promotion; network; health promotion office

\section{AZ EGÉSZSÉGFEJLESZTÉSI IRODÁK HÁLÓZATÁ- NAK LÉTREHOZÁSA}

A Széchenyi Terv keretében 2011-ben kiírt, TÁMOP6.1.2/11/3 és TÁMOP-6.1.2/11/LHH/B kódszámú pályázati felhívások nyomán Magyarországon 61 egészségfejlesztési iroda (továbbiakban EFI) jött létre és kezdte meg múködését 2013 és 2014 folyamán. A kialakított irodák közül 20 található leghátrányosabb helyzetű (LHH) és 18 hátrányos helyzetű $(\mathrm{HH})$ járásban. A népegészségügyi szervezetrendszer egyik alapját képező irodák létrehozásának alapvető célja a szív-érrendszeri és daganatos megbetegedések prevenciójának támogatása, a korai és elkerülhető halálozás csökkentése, az egészséget meghatározó életmód, valamint az egészségmagatartást befolyásoló szokások, attitúdök javítása és a lakosság egészségtudatosságának növelése volt. A pályázati kiírásban fontos célként jelent meg, hogy az egészségfejlesztési irodák intézményi hátteret biztosítsanak a betegségmegelőzési, egészségfejlesztési tevékenységhez oly módon, hogy aktívan múködtetik, tartós helyi, kistérségi hálózatba integrálják az egészségfejlesztési tevékenységet végző szervezeteket. Tehát nemcsak megvalósítják a helyi szintű egészségfejlesztési tevékenységeket, hanem összefogják a kapcsolódó helyi szervezeteket, koordinálják a közös munkát. Ezen túlmenően fontos célkitǔzés volt az is, hogy a helyi érdekhordozókat és véleményformálókat is minél nagyobb mértékben érdekelté tegyék abban, hogy hatékonyabban valósuljanak meg az adott járásban az egészségnevelési és egészségfejlesztési programok.

\section{AZ EFI HÁLÓZAT MŰKÖDÉSÉNEK TAPASZTALA- TAI}

A Nemzeti Egészségfejlesztési Intézet EFI koordinációs csoportja által múködtetett adatgyújtési rendszer adatai és az EFI munkatársainak projektidőszakhoz kapcsolódó tapasztalatai alapján az EFI-k fő szakmai tevékenységi körei a következő területekre oszthatóak:

- EFI irodában, az EFI munkatárs által végzett állapotfelmérés, kockázatbecslés és tanácsadás;

- az EFI irodák közösségi helyein megvalósuló, szakemberek által végzett szakmaspecifikus tanácsadás (pl. dietetikus tanácsadás, pszichológus tanácsadás);

- települési színtéren végzett szürések, egészségnapok szervezése és megtartása, közösségi egészségfejlesztési programok megvalósítása;

- egyéb szervezetek (önkormányzatok, civil szervezetek, iskolák, és Népegészségügyi Főosztályok) által tartott rendezvényeken történő részvétel egy programelem megtartásával;

- helyi hálózati aktivitás elősegítése, partnerhálózat kiépítése.

A következőkben az EFI-k főbb tevékenységi köréről gyűjtött számszerűsíthető adatok bemutatására térünk ki (partnerhálózat, közösségi programok, egyéni állapotfelmérés és tanácsadás). Az adatgyújtés alapján az EFI-knek összesen 1151 partnerszervezettel van kapcsolatuk. Az EFI-k által megadott adatok alapján a partnerszervezetekkel történő együttmúködések túlnyomó része valamilyen konkrét tevékenység (például, testmozgás programok 
megvalósítása, betegklubok múködtetése) megvalósítására kialakított együttmúködési megállapodás keretében történik, az általános, egész projektre szóló együttmúködések és az informális együttmüködések aránya jelentősen kisebb. Az EFI-k partnerei főleg egészségügyi intézmények, önkormányzatok és önkormányzati szervezetek, sportklubok, betegklubok. A közösségi programokat tekintve a projektidőszakban az EFI-k összesen 2404 közösségi egészségfejlesztési programot valósítottak meg. Ez átlagosan, EFI-nként 39 programot jelent (egy program általában több alkalomból tevődik össze). Az egészségfejlesztési irodák közösségi egészségfejlesztési és egészségnevelési programjain összesen 158328 fő vett részt. Az EFI-k tevékenységi körének harmadik fő része az egyéni állapotfelmérés és kockázatbecslés. Ennek során kérdőívek és antropometriai vizsgálatok segítségével felmérik az adott kliens egészségi állapotát és a fő egészségügyi kockázatait. Az állapotfelmérés alapján pedig egyéni tanácsadásban részesítik az adott klienst. Az EFI-k által állapotfelmérésen átesett kliensek száma a projektidőszak végéig összesen 170927 fő.

\section{AZ EGÉSZSÉGFEJLESZTÉSI IRODÁK TERÜLETI EL- HELYEZKEDÉSE JÁRÁSOK SZERINT}

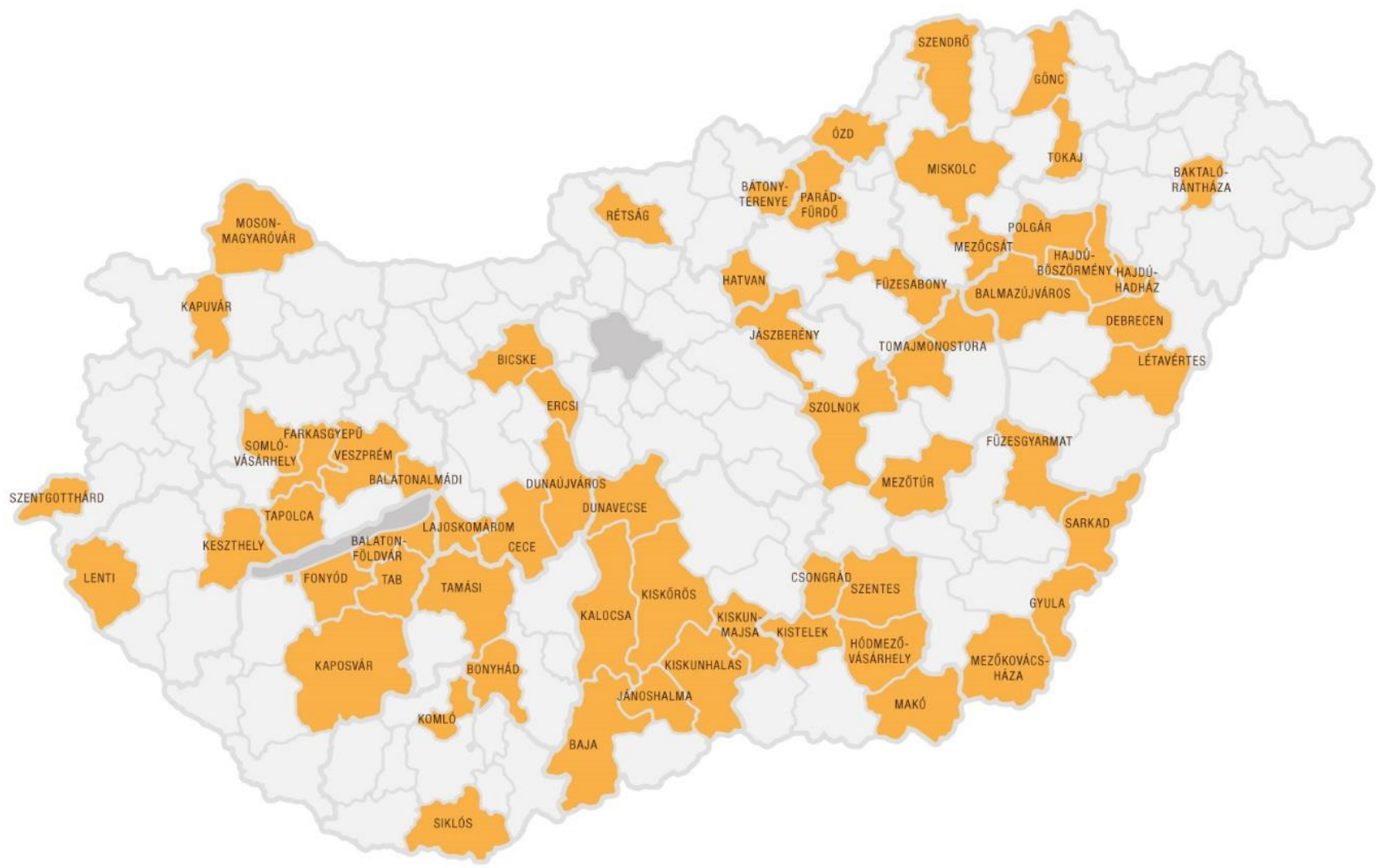




\section{EFI HÁLÓZAT A JÖVŐBEN}

Az egészségfejlesztési irodákat létrehozó egyes projektek 2015 folyamán folyamatosan futottak ki és a legkésőbb induló irodáknak is 2015. október 31-én véget ért a projekt és elkezdődött a fenntartási időszak. A fenntartási időszak finanszírozására már a 2015. évi központi költségvetésben is rendelkezésre állt a forrás, így a létrehozott EFI-k a projekt zárása után megszakítás nélkül folytathatták a megkezdett munkájukat. 2015-ben összesen 902 millió Ft múködési támogatás került elkülönítésre, az egyes EFI-kre lebontva ez havi 2,1 millió Ft múködési támogatást jelentett. A 2016. évi központi költségvetésben szintén elkülönített forrás áll rendelkezésre az EFI-k éves működési támogatásának finanszírozásához, összesen 1,537 milliárd Ft összegben. Az egy EFI-re jutó havi múködési támogatás összege nem változott az előző évhez képest, maradt havi 2,1 millió Ft. A már múködő EFI-k múködésének támogatása mellett az EFI hálózat bővitése, illetve a már meglévő EFI-k funkcióbővítése is a tervek között szerepel. Az erre vonatkozó Emberi Erőforrás Operatív Program
(EFOP) kiírás várhatóan az év folyamán kerül meghirdetésre. Az EFOP kiírás segítségével a következő évekre elérhető, hogy a járások közel kétharmada már rendelkezzen EFI-vel. Az országos lefedettség felé történő elmozdulás azért is kiemelten fontos, mivel az 1997. évi CLIV. törvény az egészségügyről 2016. januárt 1-től hatályba lévő módosítása előírja a járásszékhely önkormányzatainak a járási egészségterv kidolgozását és megvalósítását, ott, ahol van, az egészségfejlesztési iroda bevonásával. Ez azért is mérföldkő az EFI hálózat számára, mivel először szerepel jogszabályban az egészségfejlesztési iroda megnevezés és először kapcsolódik hozzá meghatározott feladat. A fenntartási időszak múködési támogatása, a hálózat EFOP forrásból történő bővítése és az EFI-k egyes feladatainak jogszabályban történő rögzítése mind azt vetíti előre, hogy az EFI hálózat hosszú távon ténylegesen betöltheti a kialakításkor megfogalmazott célt, hogy helyi szintű intézményi hátteret biztosítson a betegségmegelőzési, egészségfejlesztési tevékenység megvalósításához és koordinálásához. 